\title{
From North Africa to Latin America and Back: Comparative Findings and Theoretical Reflections
}

\author{
Irene Weipert-Fenner and Jonas Wolff
}

\subsection{INTRODUCTION}

Since the revolutions of 2011 , the transformations of the political regimes in Egypt and Tunisia have taken different paths: In Egypt, under President Abdel Fattah el-Sisi, authoritarian rule is being restabilized, while Tunisia has undergone a gradual, yet fragile, institutionalization of democratic rule. Despite these divergent trajectories, some remarkable similarities characterize post-revolutionary developments in the two countries. Until 2013 , there was a tremendous increase in polarization between secular and Islamist forces, leading to serious political crises. In this context, issues related to socioeconomic development, social policies and economic reforms were largely marginalized within the political agenda. In both countries, the predominant state response during the first years after the revolutions was marked by pragmatic muddling through that refrained

\footnotetext{
I. Weipert-Fenner $(\bowtie) \bullet J$. Wolff

Peace Research Institute Frankfurt, Frankfurt am Main, Hessen, Germany e-mail: weipert-fenner@hsfk.de; wolff@hsfk.de

(C) The Author(s) 2020

I. Weipert-Fenner, J. Wolff (eds.), Socioeconomic Protests in MENA and Latin America, Middle East Today, https://doi.org/10.1007/978-3-030-19621-9_10
} 
from pursuing structural and/or redistributive reforms. Post-revolutionary governments in Egypt and Tunisia have been unable and/or unwilling to improve the socioeconomic situation of the general populace, and, as a result, the socioeconomic grievances that were key drivers of the 2010-2011 uprisings have remained unaddressed (see Chap. 2, in this volume; Diwan and Galal 2016; IMF 2014; Kienle 2015; Paciello 2013).

As the studies compiled in this volume document, this overall dynamic of politico-economic development has had complex consequences for those actors that have continued to articulate socioeconomic grievances. But, taking the different case studies together, one general observation stands out: Key agents of socioeconomic contention, including movements by organized labor and the unemployed that were important in the run-up to the uprisings and that saw their political opportunities open up in the immediate aftermath of the revolutions, have since been effectively marginalized as political actors. In this concluding chapter, we reflect on the causes of this weakness of socioeconomic contention by identifying comparative insights that emerge from the contributions to this volume and by situating them in the context of broader comparative and theoretical debates on the relationship between social movements and political change. More specifically, in what follows, we first discuss Egypt's and Tunisia's post-revolutionary trajectories from a comparative perspective. Second, we discuss these comparative findings in the light of experiences in Latin America. Third, drawing again on comparative scholarship on Latin America, we offer a theoretical interpretation of some of the main dynamics observed in Egypt and Tunisia. Fourth and finally, we conclude with some general implications and an outlook.

\subsection{EgYPT'S ANd Tunisia's POST-REVOLUTIONARY Trajectories: Comparative Findings}

With all the talk about the "revolutions" in Egypt and Tunisia, it is important to start with acknowledging that the uprisings in 2010 and 2011 in the two countries do not even remotely correspond to what the comparative literature usually calls "revolutions." Certainly, the two countries have not experienced social revolutions, that is, "rapid, basic transformations of a society's state and class structures" that "are accompanied and in

\footnotetext{
${ }^{1}$ For a comprehensive discussion of the (non-)revolutionary nature of the Arab uprisings, see Bayat (2017).
} 
part carried through by class-based revolts from below" (Skocpol 1979, p. 4). In the terminology used, for instance, in Skocpol's classic study on the topic, the uprisings in Egypt and Tunisia could perhaps be considered political revolutions, which "transform state structures but not social structures," and "are not necessarily accomplished through class conflict" (Skocpol 1979, p. 4). But, as Adly and Meddeb (see Chap. 2, in this volume) show, even this categorization overestimates the depth of structural change that followed from the toppling of long-standing dictators. Rather than directly touching upon state structures, the so-called revolutions in Egypt and Tunisia mainly concerned the shape and configuration of political institutions, that is, the political regime. ${ }^{2}$ More specifically, what we could observe in the two countries in 2011 were protest-driven, negotiated processes of regime transformation that involved attempts to construct some kind of democratic rule (see Della Porta 2014; Heydemann 2016; Valbjørn 2012). ${ }^{3}$ This particular type of politico-institutional transformation, which can still be described as a political revolution based on the more general understanding of the term (Goodwin 2001, p. 4), serves as the "post-revolutionary" context in which the socioeconomic protests unfolded that have been studied in this volume. ${ }^{4}$

This specific characteristic of the revolutions at hand has crucial implications that run through the analyses presented in this volume and, in particular, concern the type of actors and alliances involved in contentious action. Very clearly, the correlations and alliances of actors that shaped the uprisings and their aftermath were not defined by socioeconomic (class) cleavages. Protest movements were decidedly cross-class (Della Porta 2014, Chap. 3; Durac 2015). The terminology of the comparative study of revolutions, again, helps to clarify this point: While, as already mentioned, the results of the uprisings in Egypt and Tunisia can be called political revolutions (in a broad sense), the uprisings themselves were

${ }^{2}$ On the distinction between state and political regime, see, for instance, Fishman (1990), Goodwin (2001, pp. 12-13), and O'Donnell (1993).

${ }^{3}$ In terms of the typology of "paths toward democracy" developed by Ruth B. Collier, Egypt and Tunisia roughly correspond to the pattern of "destabilization and extrication," in which protest movements (in Collier's cases, sustained by organized labor, in particular) "destabilized authoritarianism and opened the way for the establishment of a democratically elected government" (Collier 1999, p. 114).

${ }^{4}$ In such a broader sense, Jeff Goodwin (2001, pp. 9-10) defines revolutions as "irregular, extra-constitutional, and sometimes violent changes of political regime and control of state power brought about by popular movements." 
hardly driven by a network of actors that might be considered "revolutionary movements," that is, social movements that "attempt to gain control of the state as such" (Goodwin 2001, p. 10). As almost all observers have noted, socioeconomic claims were significant in the emergence and spread of the uprisings, and actors that are defined by socioeconomic cleavages (such as labor organizations or the unemployed) played an important role in the dynamics of mobilization (see Chap. 1, in this volume). And, yet, no relevant sociopolitical force emerged from these protests that would promote anything resembling an agenda for socioeconomic change. This helps understand one key finding of the research compiled in this volume: the apparent paradox that uprisings that (a) have been driven, in particular, by socioeconomic grievances and related demands for social justice and that (b) have had sufficient strength to topple long-standing dictators, have (c) not led to any significant fulfillment of these socioeconomic demands. But what are the implications of this mismatch between the claims and the actual outcomes of the uprisings for the postrevolutionary dynamics of contentious action?

In the immediate aftermath of the uprisings, many observers argued that a decisive question for the future of the ongoing political transformations in Egypt and Tunisia was precisely whether post-revolutionary governments would be able to address "citizen demands for material improvement and social justice" (Burnell 2013, p. 84; see also Schlumberger and Matzke 2012, pp. 107-108). When we started this project, we therefore speculated that a lack of a substantive political response to socioeconomic grievances in Egypt and Tunisia would mean that socioeconomic protests would go on at a continuously high, if not increasing, level. In any case, we expected that the ways in which the emerging political regimes in Egypt and Tunisia "respond to socioeconomic discontent are of crucial importance for [the] political transformation processes" (Weipert-Fenner and Wolff 2015, p. 1). These assumptions have not been disproven by our research, but the findings of this book do suggest a need for differentiation.

As the quantitative protest event analysis conducted by Prisca Jöst and Jan-Philipp Vatthauer shows, socioeconomic protests have not been a continuous phenomenon. The years between 2011 and 2016 in the two

\footnotetext{
${ }^{5}$ Goodwin, here, relies on Charles Tilly's definition of a revolutionary movement as "a social movement 'advancing exclusive competing claims to control of the state, or some segment of it"” (Goodwin 2001, p. 10, citing Tilly 1993, p. 10).
} 
countries have been characterized rather by passing outbursts of discontent, most notably in Egypt in 2013 and in Tunisia in 2016. Since 2013, socioeconomic protests in Egypt have continued, albeit at a low level of intensity. Tunisia, by contrast, has witnessed a massive increase in socioeconomic protests since 2015, which, however, has also taken the form of temporary outbursts. In line with the political opportunity approach in social movement research, these dynamics of socioeconomic contention respond to the evolving political context rather than constituting a relevant driving force of political change. Still, socioeconomic contention has proven relevant for economic policymaking: Arguably in response to protests, including the threat thereof, governments in both Egypt and Tunisia have increased public wages, the size of the public sector and general subsidies (at least in the first years after the revolutions), while refraining from pursuing socioeconomic measures that would have had immediate negative effects on wage earners and self-, under- and unemployed people (see Chap. 2, in this volume; IMF 2014, pp. 8-11; Paciello 2013).

This overall finding is confirmed upon inspection of the key protagonists in socioeconomic protests in the two countries, namely organized and unorganized labor and, in Tunisia, unemployed people. In both countries, while labor organizations were relatively successful in defending certain benefits and rights, they were unable to achieve "positive" change. This holds true for both Tunisia, where the unusually strong and united national trade union federation Union Générale Tunisienne du Travail (UGTT) has mainly acted as a mediator, contributing to the contested process of political transition in the country (see Chap. 5 , in this volume), and Egypt, where the main trade union federation remains under state control and the independent trade union movement has become increasingly marginalized. Still, even in Egypt, independent trade unions successfully prevented parliament from adopting a new civil service law in early 2016 that included reductions in public sector wages (see Chap. 6, in this volume). The protests by organized and ad hoc groups of unemployed people in Tunisia were also characterized by conservative demands. Actions by the national Union of Unemployed Graduates (UDC) and mobilizations in the Gafsa mining basin-a hotbed of socioeconomic protest in Tunisia-have generally called for a return of the state as the guarantor of decent jobs and welfare. ${ }^{6}$ Success, therefore, has basically meant

\footnotetext{
${ }^{6} \mathrm{~A}$ different dynamic, but with similar consequences, could be observed in the case of Egypt's Tuktuk drivers studied in this volume by Abdelrahman Soliman. Here, also, the few
} 
governmental assurances of a certain number of additional public sector jobs for the unemployed (see Chap. 8 , in this volume). The case studies also revealed that the fragmentation of societal actors and their low levels of trust in political parties and institutions have contributed to the weakness of socioeconomic protests (see Chaps. 6, 8 and 9 of this volume). The only exception is the Tunisian trade union federation, which has by and large been able to represent the country's organized working class. Given its political role as a mediator guaranteeing Tunisia's transition to democracy, the UGTT has, however, largely refrained from actively making labor-related, socioeconomic demands (see Chap. 5 , in this volume). In addition, even if it generally has a leftist profile, the UGTT has presented itself as a nonpartisan, "neutral" actor and, therefore, mostly refrained from forming alliances with political parties.

\subsection{Egypt and Tunisia in the Light of Latin American Experiences: InTERregional Comparison}

As summarized in the two overview chapters by Jonas Wolff (see Chaps. 4 and 7 , in this volume), studies on the role and dynamics of social protest and popular mobilization during the processes of democratization in Latin America between the late 1970s and early 1990s have shown how socioeconomic claims, though important for mobilization against authoritarian regimes, were sidelined during actual regime change negotiations.

By and large, democratization in the region meant the establishment of, or return to, a political system with free and fair elections, representative political institutions and constitutionally guaranteed political and civil rights. It did not include any serious attempt to deal with the dramatic socioeconomic inequalities and the systematic disregard of social and economic rights with a view to improving the socioeconomic underpinnings of a more-than-formal democracy. Some observers have explicitly argued that things have to be like this: that in order to get the moderate ("soft") members of the authoritarian regime coalition to support democratization, debates about economic redistribution and structural, socioeconomic change had to be avoided (see O'Donnell and Schmitter 1986, p. 27). Others have rather grudgingly accepted that this

protests that took place were characterized by defensive and/or conservative demands on the state, basically aiming at the issue of licensing. 
is what happened empirically (see Bermeo 1990, p. 365). ${ }^{7}$ Be this as it may, the overall result is undeniable: Political democratization in Latin America succeeded in a context of persisting - if not actually worseningsocioeconomic hardships and inequalities and, thus, did not actually produce socioeconomic benefits for the great majority of the respective population that was, formally, empowered by political change. Recalling the ways in which this general dynamic played out in the region as well as the explanations that have been developed in the comparative literature on Latin American democratization help us better understand the contemporary trajectories of post-revolutionary Egypt and Tunisia as summarized earlier. This, in particular, concerns three key dynamics that can be observed in both contexts.

First, as mentioned earlier, in both sets of cases, we can observe that as soon as the struggle is over, and the negotiation of the shape of the political regime takes center stage, questions concerning the economic order and socioeconomic redistribution are pushed aside in the political agenda. Theoretically, in the case of Latin America, this dynamic can be traced back to (a) the cross-class character of the pro-democracy movements and the relatively privileged status of the Latin American middle classes (including the important segment of organized labor), which made the emergence of a common agenda of socioeconomic change and, more specifically, widely shared claims for socioeconomic redistribution unlikely; (b) the elite-centered and negotiated (non-revolutionary) character of most transitions, which meant that incumbent regime forces and political, military and economic elites, in general, played an important role in shaping political change; and (c) an international context that, by and large, supported this kind of limited, politico-institutional democratization (see O'Donnell and Schmitter 1986; Rueschemeyer et al. 1992, Chap. 5; Wolff 2005, p. 61). The contributions to this volume suggest that these three factors are also relevant in the cases of Egypt and Tunisia. While (a) the cross-class character of the uprising and its consequences for the post-revolutionary dynamics of contention have already been highlighted, the ambivalent

${ }^{7}$ As Nancy Bermeo summarized the findings of the set of volumes on Transitions to Authoritarian Rule, the "facts," while dismaying to everyone who, like herself, values "political and economic egalitarianism, "are undeniable": "Virtually none of the surviving transitions to democracy that are discussed in this collection combined a significant redistribution of political and economic resources. In every enduring case, dramatic redistributions of property were postponed, circumscribed, or rolled back." (Bermeo 1990, p. 365; see also Karl 1990). 
role of organized labor in Egypt and Tunisia also resembles the Latin American experiences. As the chapters by Abdalla and Karray (see Chaps. 5 and 6 , in this volume) show, key trade union organizations in both countries have been much more active in defending their (privileged) position than in trying to articulate a progressive socioeconomic agenda in the name of the broader popular sectors. In the case of Tunisia, this attitude is directly reflected in the tensions between the UGTT (at the national level) and the mobilization of unemployed people (see Chap. 8, in this volume). Even if these dimensions have not been studied in detail in this volume, it is also clear that (b) incumbent regime forces and elites, in general, were also key actors in the contested negotiations of political change in the two North African cases (see Boubekeur 2016; Roll 2016), and that (c) the international context-while certainly heterogeneous in terms of its political implications-tended to support austerity policies and neoliberal reforms and, in any case, did not favor any kind of progressive socioeconomic reform agenda (see Hinnebusch 2015; Paciello 2013; Teti 2012).

Second, in the "historic" context of politico-institutional change with socioeconomic continuity in Latin America, popular-sector organizations that had originally voiced socioeconomic demands either (a) joined the trend and likewise started to focus on politico-institutional issues, (b) tried to continue pushing for a broader socioeconomic agenda but faced increasing fragmentation and marginalization from the political debate or (c) turned inward and/or to the local area and focused on survival strategies and self-help activities. The case studies included in this volume certainly do not cover (not nearly) the broad range of popular-sector organizations in Egypt and Tunisia, but the available evidence-again-reveals comparable dynamics. In terms of (a), in the two post-revolutionary contexts, the Tunisian UGTT stands out as a labor organization that can be considered a relevant—and, indeed, quite powerful — political actor. But, as Karray's chapter (see Chap. 5, in this volume) demonstrates, the UGTT's role has been strong precisely as a participant in the politico-institutional transition process - at the expense of a socioeconomic agenda that, for instance, would have worked toward meeting specific workers' demands. The issue of fragmentation and marginalization (b), which also showed up in the quantitative protest event analysis, has already been mentioned as a general feature in both countries, and it was particularly pronounced in the case of Egypt's independent labor movement and the different types of unemployed mobilization in Tunisia. Finally (c), in different ways and forms, the case studies of the Egyptian Tuktuk drivers and the protests in 
Tunisia's Gafsa mining region revealed patterns of (partially contentious) interactions with the state that follow a rather "unpolitical"-localized and self-help-oriented-logic (see Chaps. 8 and 9 in this volume).

This last observation points to the third dynamic: the political consequences of these patterns of contentious action. As already suggested, the overall phenomenon in both sets of cases is that socioeconomic grievances that contributed to motivating popular resistance to authoritarian regimes in the first place were not addressed and, correspondingly, socioeconomic contention continued-but it did (or does) so taking localized and/or fragmented, actor- and/or issue-specific forms that have a significant impact at the macropolitical level. As research on contentious action in Latin America's post-transition democracies shows, the combination of persisting socioeconomic grievances with the opening of political opportunities in this region—surprisingly — did not lead to ever-more escalating popular protest. Rather, what scholars have described is an overall process of "demobilization of the popular sectors" (Oxhorn 1998, p. 208) characterized by an "angry atomization of society" (O'Donnell 1993, p. 1365) and erratic, short-lived expressions of discontent at the national level (Portes and Hoffman 2003, pp. 76-77), as well as new territorialized forms of popular-sector mobilization at the local level (Rossi 2017, pp. 13-15). Thus, the relative absence, or reduction, in popular protests, making socioeconomic claims at the national level did not imply satisfaction, but rather reflected politico-economic dynamics that concern both the internal mechanisms of organization and mobilization among the popular sectors and their relationship with the broader political, economic and international context (see the two overview chapters on Latin America, Chaps. 4 and 7 , in this volume). This is, in general terms, what we also find in post-revolutionary Egypt and Tunisia. More specifically, the case studies of Egypt's independent labor movement and Tunisia's unemployed movement emphasized the internal weakness of existing popularsector organizations, the lack of reliable and relevant sociopolitical allies and a political context that severely limited (Egypt) or limited to a relative degree (Tunisia) meaningful access to the political system.

\footnotetext{
${ }^{8}$ In her 1989 book on Power and Popular Protest, Susan Eckstein (1989, p. 41) still speculated that, in particular, in the context of open and thus protest-prone democratic regimes, the combination of increasing socioeconomic hardships due to region-wide economic crises and reduced state capacity for diffusing potential unrest with "patronage and subsidies" due to the austerity programs might lead to increasing levels of popular protest. See also O'Donnell and Schmitter (1986, pp. 52-53).
} 
As an overall result, it has been argued, with regard to Latin America, that in the end the non-responsivity to social grievances of the posttransition regimes proved instrumental for the stability of the posttransition regimes, as it helped avoid elite resistance to the "risks" that democratization posed for their privileges in terms of power and wealth (see Chaps. 4 and 7, in this volume). Although this was not studied in this volume, it is at least plausible to argue that democratization in Tunisia has benefited from a similar dynamic: In a context of significant mobilization around (class-based) socioeconomic cleavages, it certainly would have been hard to establish the kind of alliances that were key elements in the negotiated transition to democracy, such as the National Dialogue Quartet that united the UGTT and the Tunisian Confederation of Industry, Trade and Handicrafts (UTICA) or the different party coalitions that brought together an Islamist party with social-democratic parties or with a conservative party alliance, respectively.

To be sure, these overall dynamics represent general patterns only. In the case of Latin America, in the 1980s and early 1990s, several countries saw quite important waves of socioeconomic contention. But these protests were, on the one hand, defensive reactions to austerity policies and neoliberal reforms rather than proactive moves demanding socioeconomic change-again something we can also observe in protest dynamics in Egypt and Tunisia. On the other hand, while governments in post-transition Latin America did frequently respond with repression, the ultimate failure of these protests to prevent the kinds of (neoliberal and/or austerity) policies they were fighting was not due to overwhelming state repression (see the two overview chapters on Latin America, Chaps. 4 and 7, in this volume). ${ }^{9}$ In the case of Egypt — which has (for the time being) seen the re-establishment of authoritarian rule, with levels of restrictions on civil society organizations that even exceed the pre-revolutionary situation - the political repression of (potentially) contentious actors is clearly a factor also evident in the low numbers of overall protests since the coup against Morsi (see Chap. 3, in this volume). Tunisia, for obvious reasons, much more closely resembles Latin America's post-transition experiences in this regard.

\footnotetext{
${ }^{9}$ As Eckstein (1989, p. 47) noted in the late 1980s, "Latin American governments do not have the material capability of employing force on a large scale unless financed from abroad, and the democratic countries in the region cannot, for ideological reasons, rely on prolonged and extensive use of force to rule." Repression, under these conditions, tended to strengthen, rather than weaken, movements (Eckstein 1989, p. 46).
} 


\subsection{Contentious Politics in Times of Incorporation Crises: Theoretical Reflections}

Comparing Egypt and Tunisia brings a remarkable pattern of similarities and differences to the fore. First, as we have seen, there is a quite high level of convergence between the two countries when it comes to the very characteristics of the uprisings that culminated in the toppling of long-standing dictators in early 2011. Second, however, the trajectories of political transformation after the revolutions are pointed in opposite directions. Third, these diverging political contexts notwithstanding, post-revolutionary Egypt and Tunisia again display quite similar patterns in economic policymaking and, in general terms, in their respective lack of general structural economic change. Fourth, quantitative trends in socioeconomic protests are very different (clearly reflecting the differences in political opportunity structures rather than socioeconomic similarities). But, fifth, key qualitative characteristics of these socioeconomic protests are again fairly similar (fragmented, territorialized, issue-specific, etc.), and this common weakness is, sixth, reflected in the (limited and mainly status quo-oriented) consequences of these protests, which do not significantly reflect the dramatically different degrees of access to the political system that would be expected, given the diverging politico-institutional contexts.

In a nutshell, this pattern suggests that the politico-institutional context significantly shapes the quantity and intensity of (socioeconomic) protests (as predicted by the contentious political approach), but that the qualitative characteristics of the socioeconomic protests, which have more immediate consequences in macropolitical terms, are shaped by different conditions. In order to make theoretical sense of this observation, it is again helpful to turn to an academic literature that has emerged in the comparative study of Latin American politics, namely the debate on the question of incorporation.

In a landmark study first published in 1991, Ruth and David Collier analyzed the historical processes through which the labor movement was initially incorporated into the political system during the first half of the twentieth century. Studying and comparing the cases of Argentina, Brazil, Chile, Colombia, Mexico, Peru, Uruguay, and Venezuela, they identified different strategies and types of labor incorporation, which led to varying patterns of conflict and accommodation and produced long-lasting legacies in terms of party system development and political regime dynamics 
(Collier and Collier 2002). ${ }^{10}$ Recently, scholars have revived the concept of incorporation arguing that, since the 1990s, Latin America has been experiencing a new incorporation crisis that, with the so-called left turn, has given way to a "second historical process of mass political incorporation" (Roberts 2008, p. 300; see Luna and Filgueira 2009; Rossi 2015, 2017; Silva 2017). In contrast to the first period of incorporation, the new period of incorporation involves a much more heterogeneous set of social groups that, in the Latin American debate, is usually called "the popular sectors." Generally speaking, their incorporation has two dimensions: a political dimension that concerns the inclusion of popular-sector claims and interests into the political agenda as well as "the concrete mechanisms that link popular sector organizations to the political arena and policymaking" (Silva 2017, p. 95; see also Rossi 2017, p. xi) and a socioeconomic dimension that refers to the substantive efforts at socioeconomic inclusion through the strengthening of socioeconomic rights and/or corresponding social and economic policies (Luna and Filgueira 2009, p. 375).

The recent wave of popular-sector struggles across Latin America, which in the first decade of the twenty-first century led to the election of a whole series of leftist and center-left governments, followed from the consequences of neoliberal reforms in two regards: On the one hand, the broken promise of neoliberal incorporation ${ }^{12}$ was a key driving force in the

\footnotetext{
${ }^{10}$ Studying the emergence of organized labor movements in Latin America as well as the varying responses of the state to this new phenomenon, Collier and Collier identified different types and patterns of what they call the "initial incorporation" of the labor movement. As a critical juncture, the shape of this incorporation, then, was shown to have long-term effects on party systems and regime dynamics in the respective countries. Most notably, they distinguish between two different types of incorporation: In cases of state incorporation, "the legal and bureaucratic apparatus of the state" was the key agency of incorporation, "and the principal goal of the leaders who initiated incorporation was the control and depoliticization of the labor movement"; in cases of party incorporation, by contrast, "a central agency of incorporation was a political party or political movement that later became a party, and a fundamental goal of political leaders, in addition to control, was the mobilization of working class support through this party of movement" (Collier and Collier 2002, p. 8).

${ }^{11}$ Eduardo Silva defines the popular sectors as "poor subaltern social sectors," including both "urban poor social groups in the formal and informal labor sectors" and "peasants, indigenous peoples, and other peoples of color in urban and rural spaces organized on socioterritorial bases" (2017, p. 116, note 1).

${ }^{12}$ Luna and Filgueira characterize Latin America's pattern of (failed) incorporation in the 1990s as "electoral incorporation in the context of faulty democracies and segmented market incorporation" and argue that "[n] eoliberalism did not fail simply because of its inability in most Latin American settings to achieve stable growth, wealth redistribution or market
} 
upsurge of social (protest) movements that many Latin American countries have experienced since the late 1990s (see Roberts 2008). On the other hand, neoliberal reforms generally meant a process of "disincorporation" of organized labor, which saw itself dramatically weakened both in socioeconomic and in political terms (Rossi 2017, pp. 15-17); in general, the "fragmented, heterogeneous popular sector landscape," from which new dynamics of contentious mobilization have emerged since the late 1990s, were very much the socio-structural result of neoliberalism (Silva 2017, p. 95). ${ }^{13}$ These popular sectors, while formally empowered by the establishment of democratic regimes during the long 1980s, were de facto marginalized in both political and socioeconomic terms in the context of democratization-cum-neoliberal reforms (see Kurtz 2004; Oxhorn 1998; Wolff 2005, pp. 62-67, 2007, pp. 10-13).

The election of left and center-left governments across the region as well as the series of socioeconomic and politico-institutional changes that this left turn has brought about can, therefore, be understood "as both the outcomes of, and a set of alternative solutions to, a 'second incorporation crisis" (Luna and Filgueira 2009, p. 372). Important differences between the left and center-left governments that came to power in many Latin American countries in the early 2000s notwithstanding, their overall agenda has combined (a) a turn to post-neoliberal social and economic policies that aimed at socioeconomic incorporation of the popular sectors (basically, by reducing poverty and income inequality) and (b) varying attempts to politically incorporate the popular sectors (via popular-sector organizations such as labor unions or social movement organizations representing, for instance, indigenous or unemployed people; via leftist and/ or movement-type political parties; via new mechanisms of participatory and/or plebiscitary democracy).

In the context of this concluding chapter, it is impossible to discuss the specific patterns and actual outcomes of incorporation in Latin America (see Rossi 2017; Silva and Rossi 2018; Wolff 2018). Suffice it to say that progress in terms of both socioeconomic and political inclusion was diverse but real. Yet, it remained relative only and its sustainability doubtful, given

incorporation, but also because it was unable to structure political incorporation by providing legitimate representation (i.e., by delivering policies and outcomes that were able to synchronise collective expectations and individual needs)" (2009, p. 376).

${ }^{13}$ To be sure, neoliberal structural adjustment in this regard combined with austerity policies, monetary stabilization measures, the effects of the severe economic crisis of the 1980s, as well as with the consequences of the military dictatorships. 
that socioeconomic inclusion depended to an important extent on high commodity prices, while political inclusion frequently depended on informal mechanisms. In sum, therefore, the crisis of incorporation which has underlain Latin America's "leftist turn" is, thus, far from resolved. What is relevant for our purposes, however, is the overall idea of incorporation periods-incorporation crises and attempted solutions of such criseswhich result from basic socio-structural changes (but, to be sure, have to be activated through processes of social mobilization). As we will suggest in the following, considering them as expressions of a fundamental crisis of incorporation helps to make sense of the empirical observations collected in this volume.

In fact, the Arab uprisings have already been interpreted as resulting from the breakdown of an "authoritarian social contract" that had sustained the autocratic regimes in the region for many decades (see Achy 2015; Guazzone and Pioppi 2012; Zorob 2013). Generally speaking, this social contract (in Egypt and Tunisia but also elsewhere in the region) involved key mechanisms of incorporation: In political terms, state corporatism was a key feature which basically connected organized labor with the political arena through a state-controlled and co-opted labor movement (other mechanisms of political incorporation included, for instance, parliaments that, in the same way, served to connect key constituencies to the political regime, see Weipert-Fenner 2015). In socioeconomic terms, research has particularly highlighted the material benefits offered by the authoritarian regimes (jobs in the public sector, social security, social subsidies, etc.). With neoliberal structural adjustment, this authoritarian social contract gradually lost its material basis, while (partially related) changes in the social and economic structures of the countries meant that corporatist arrangements reached a decreasing share of the popular sectors. The resulting crisis of incorporation has become manifest with the rise of an independent labor movement in Egypt since 2006, the 2008 protests in Tunisia's Gafsa region and, finally, with the uprisings of 2010-2011.

As our analysis of post-revolutionary dynamics in Egypt and Tunisia shows, these old mechanisms of incorporation still exist. Furthermore, key ideological elements of the authoritarian social contract continue to shape the popular discourses and agendas of key actors (as exemplified by Tunisia's unemployed protests and their primary demand to be hired by the state). Yet, a persisting crisis of incorporation is hard to deny. Post-revolutionary developments have, therefore, not meant a re-establishment of the earlier scheme of incorporation. The extremely repressive turn in the Egyptian 
government's relationship with civil society actors, on the one hand, and the extent of public discontent as well as the recent outbursts of socioeconomic protests in Tunisia, on the other hand, clearly suggest that existing ("old") mechanisms of incorporation reach only a limited (privileged) part of the popular sectors, and they do so in increasingly precarious ways. The extent and reach of socioeconomic incorporation-through, for instance, socioeconomic measures (public sector jobs, subsidies) - is clearly insufficient. The same holds true for the politico-institutional dimension, where, for instance, the corporatist inclusion of organized labor is not only highly exclusive and state-controlled but is also largely formal, without enabling any kind of substantive influence on policymaking.

At the same time, however, new mechanisms of incorporation-which might enable a new social contract-have yet to emerge. Rather, as in Latin America in the 1980s and 1990s, current dynamics in Egypt and Tunisia fluctuate between (or combine) neoliberal approaches that emphasize inclusion "by and through the market" and fairly traditional state-centered and state-corporatist approaches. In the case of Tunisia, the idea of a "social dialogue," which has been promoted by the UGTT and which basically represents an attempt to revise corporatist incorporation in the new context, cautiously points in a more innovative direction. But, generally, our case studies document little to no new dynamics of incorporation. In different ways and gradations, this lack of any institutional articulation with the political arena can be observed in the case of the unemployed protests in Gafsa and the Tuktuk drivers in Egypt, that is, in the informal sectors of the countries but also in the labor activism in Egypt that is continuing despite the banning of independent labor unions and the renewed co-optation of the official labor union (Hamzawy 2017). Clearly, those large parts of the population that are outside the formal labor market are entirely excluded from existing mechanisms of incorporation but also important groups of formally employed people are not or are only indirectly or ephemerally part of corporatist interest intermediation.

To what extent does this interpretation of the post-revolutionary setting - as an incorporation crisis that openly broke out with the uprisings and has yet to be addressed-help understand the puzzling similarities and differences between Egypt and Tunisia? First, the notion of a persisting crisis of incorporation points to a common feature that characterizes political developments in the two countries. While the development of the 
political regimes in a narrow sense has taken divergent trajectories, the ways in which these emerging regimes incorporate (or do not incorporate) the popular sectors and their organizations reveal some important similarities. In democratic Tunisia, as in authoritarian Egypt, institutionalized access of popular-sector organizations to the political arena is as limited as the political responsiveness to their concerns. This similarity across different political regimes is hardly surprising when the Latin American experience is taken into account: The establishment of representative democracy does not automatically imply a process of popular-sector incorporation. In their comparison of Egypt and Tunisia, Adly and Meddeb (see Chap. 2, in this volume) therefore basically confirm what research on Latin America's post-transition democracies has established: That changes in the set-up of political institutions and the formal granting of universal political and civil rights as implied by democratization can perfectly coexist with far-reaching continuities in social power relations, which will, then, most probably also be reflected in the overall characteristics of social and economic policies (see Kurtz 2004; Oxhorn 1998; Wolff 2005).

Second, the dynamics of socioeconomic protests and their political relevance are also shaped by the underlying crisis of incorporation that particularly concerns the heterogeneous set of social groups that make up the popular sectors. Expressing the ongoing struggles for incorporation, protests continue with ebbs and flows in both countries and, in the much more open Tunisian context, with fairly dramatic outbursts of discontent. But, given the heterogeneity of the social groups and the fragmentation of the popular-sector organizations involved, these protests neither force authorities to respond with offers of meaningful incorporation nor do they accumulate into broader waves of contention that would (once again) challenge the political regimes. The different quantitative dynamics of socioeconomic protests in Egypt and Tunisia thus reflect the differences in the political opportunity structures, but the similar quality — and hence a similarly low degree of political relevanceof the protests is arguably related to the socio-structural and organizational set-up of the popular sectors. As in the Latin American 1990s, these characteristics of popular-sector mobilization reflect the combined legacies of decades of authoritarian rule and neoliberal structural adjustment. In sum, therefore, recognizing the unaddressed crisis of popularsector incorporation helps explain key dynamics in contentious politics in Egypt and Tunisia. 


\subsection{OUTLOOK}

At the end of the 1980s, a volume on Power and Popular Protest in Latin America started with the observation that "Latin Americans have been more defiant than the available literature would lead us to believe, even if less so than we might expect, given existing injustices and inequities" (Eckstein 1989, p. 3). The same kind of statement could well have started our analysis of socioeconomic protest in Egypt and Tunisia: The Arab uprisings of 2010-2011 and what has happened ever since clearly show that the people in the region are more defiant than previous assessments of Arab exceptionalism and authoritarian persistence suggested, even if less defiant than we might expect, given persisting injustices and inequities. In Latin America, it took roughly two decades until the failure of post-transitional (democratic) regimes to do anything about the persisting (if not aggravating) injustices and inequities led to a renewed wave of popular mobilization that placed the social question back on the agenda. In the early 2000s, this new upsurge in sociopolitical mobilization in Latin America ushered in a period of remarkable political and socioeconomic change in which left and center-left governments adopted more inclusive and redistributive ("post-neoliberal") social and economic policies and, contradictions and limitations notwithstanding, achieved significant reductions in poverty and inequality (see Huber and Stephens 2012; Levitsky and Roberts 2011; Rossi 2017; Silva and Rossi 2018).

In this concluding chapter, we have argued that Egypt and Tunisiaand plausibly broader parts of the Middle East and North Africa (MENA) region as well-are currently confronting a crisis of popular-sector incorporation that is fairly similar to the one Latin America has been facing since the 1980s (and which is still far from resolved in that region). Large parts of the population-namely those representing the lower strata of societydo not have access to effective mechanisms that link them with the political arena, give them an institutional voice in the political process and/or make policymaking responsive to their interests and values. With the popular uprisings of 2010-2011, this lack of incorporation, which reflects the breakdown of the previous scheme of incorporation (the "authoritarian social contract"), turned into a full-fledged crisis. In both post-revolutionary contexts studied in this volume, governments have been unwilling to establish new processes for incorporating organizations representing the popular sectors, while the latter have been mostly unable to apply pressure for their incorporation from below. This dynamic is remarkably similar in 
Egypt and Tunisia, despite the different political regimes that have taken shape in the two countries. This observation reinforces our argument that we are confronted here with underlying social (sociopolitical and politicoeconomic) dynamics that shape contentious politics and are relatively independent of changes at the level of the political system.

What are we to make of this overall assessment? The idea behind the interregional comparative perspective is definitely not that Latin America, as a somewhat more advanced region, serves to demonstrate to North Africa or the Arab world "the image of its own future," to paraphrase Karl Marx. This story is neither about late developers repeating the experiences of others, nor about models that might be exported. But, by being capitalist societies with a peripheral place in the global political economy in times of neoliberal globalization, Latin America and North Africa are part of global processes of social change and, at the same time, are experiencing processes of domestic social change that can be expected to exhibit certain common features. It is in this sense that it is promising to speculate that Egypt and Tunisia are undergoing a period of contested incorporation that is structurally similar to the one that Latin America has been experiencing since the 1990s. This analogy, in addition to helping us make sense of the empirical phenomena studied in this volume, raises three important questions that might be crucial for the future of Egypt and Tunisia (and the Arab world, more generally speaking), and with which we want to conclude this book.

First, with a view to future academic research, it seems promising to systematically address the question of incorporation (periods, crises and attempts) from an interregional comparative perspective. Informed by what we know from Latin America about mechanisms and patterns, demands and struggles, outcomes and problems of popular-sector incorporation, such a research agenda would study in detail the shifts and continuities in the ways in which different segments of the popular sectors in the MENA region create or use links with the political arena to make their demands heard and in which, stated the other way round, states and political parties use, establish or adapt links with the popular sectors. From an interregional comparative perspective, one key question is whether we can identify new dynamics of popular-sector incorporation in the MENA region that might offer (competing, more or less promising) solutions to the incorporation crisis. Such new dynamics in the MENA region may emerge from below, from the very place where 
popular-sector groups organize and act collectively or from above, as political responses to challenges from below. In the end, however, they will result from contentious politics dynamics in which social agency from below interacts with macropolitical dynamics from above. In any case, the dynamics that may already be underway in the MENA region will most certainly be very different from the ones observed in the context of Latin America's "left turn." But, as we have suggested in this concluding chapter, they respond to fairly similar social and political challenges and will, therefore, probably be characterized by structural similarities and/or functional equivalents.

Going beyond such a descriptive research agenda, a second-and related -question obviously concerns the conditions and factors that might enable or activate new dynamics of popular-sector incorporation in the MENA region in general, and in Egypt and Tunisia in particular. Again, Latin American experiences do not offer a direct answer to this question, but still might be worth considering. As briefly summarized in the second overview chapter by Jonas Wolff (see Chap. 7 , in this volume), scholars have explained the recent re-emergence of strong popular-sector movements in Latin America, which prepared the ground for the "left turn," by emphasizing the necessary combination of macro- and micro-conditions. To recap: The opportunity and the motive to mobilize were constituted by the overall political space offered by democracy as well as by the mobilizing threats implied by neoliberal reforms and austerity policies. Yet, in terms of the capacity to organize and act collectively, associational spaces and pre-existing societal networks at the local level as well as horizontal networks and communication across different local settings were crucial in enabling popular-sector groups to effectively seize the opportunities and respond to the threats (see Silva 2009; Wolff 2007; Yashar 2005).

Third, the question of incorporation is far from a purely academic issue. As the comparative scholarship on the different periods of mass incorporation in Latin America demonstrates, the patterns and dynamics of incorporation are of the utmost political importance. The ways in which the popular sectors are or are not incorporated have immediate and long-term consequences for party system development and political regime dynamics as well as for political stability and societal peace. This means that it is not only generally important to search for ways in which, say, unemployed people in Tunisia or shantytown dwellers in Egypt can gain an institutionalized voice in the political arena, it will also be crucial 
for political developments in these countries how they might eventually do so: whether by means of relatively autonomous social movements or the expansion of existing (labor) organizations, or through old or new, leftist, Islamist or whatever-kind-of parties or through state institutions and agencies. Recognizing the manifold experiences from Latin America in this regard may enable academics, politicians and activists to identify promising attempts to facilitate popular-sector incorporation that emerge in Egypt, Tunisia and beyond, as well as ways of promoting innovation in popular-sector incorporation from the outside at an early stage. To mention only one specific lesson from Latin America, promising experiments in popular-sector incorporation might particularly emerge in local settings, at the municipal level, where it is easier for social movements to establish direct and organic links with the political arena (see Goldfrank 2011; Van Cott 2008). In terms of political reforms, this raises the issue of decentralization and the question how to enable or deepen political participation at the local level.

All this is not to say that it is irrelevant whether representative democracy exists, whether individual human rights are respected or whether civil society actors in general can act autonomously and have access to the political arena. All this is certainly of crucial importance in many regards. ${ }^{14}$ But, as the focus on socioeconomic protests shows all too well, the structural inequalities that characterize societies in the Arab world as in Latin America (or, for that matter, Europe) also demand a perspective that takes social class and power relations seriously. As Ruth Collier concluded in her study on the role of the working class during democratization processes in Western Europe and Latin America, in times of political transformation, it is not "transition games but political economy [that] becomes crucially important" (Collier 1999, p. 197). In normative terms, such a perspective should specifically zoom in on those sectors of society that are struggling for survival, political empowerment and social justice from a disadvantaged position-and whose success is, therefore, of particular relevance when it comes to constructing societies that are both politically more democratic and socially more just.

\footnotetext{
${ }^{14}$ In fact, as mentioned above, scholars have emphasized the relevance of the overall political space offered by representative democracy — even if this opportunity structure was, obviously, only an enabling condition (see Levitsky and Roberts 2011; Wolff 2007; Yashar 2005).
} 


\section{REFERENCES}

Achy, L. (2015). Breakdown of the authoritarian 'social contract' and emergence of new social actors: An ongoing process? In L. Sadiki (Ed.), Routledge handbook of the Arab spring: Rethinking democratization (pp. 303-318). London: Routledge.

Bayat, A. (2017). Revolution without revolutionaries. Making sense of the Arab spring. Stanford, CA: Stanford University Press.

Bermeo, N. (1990). Review article: Rethinking regime change. Comparative Politics, 22(3), 359-377.

Boubekeur, A. (2016). Islamists, secularists and old regime elites in Tunisia: Bargained competition. Mediterranean Politics, 21(1), 107-127.

Burnell, P. (2013). Democratisation in the Middle East and North Africa: Perspectives from democracy support. Third World Quarterly, 34(5), 838-855.

Collier, R. (1999). Paths toward democracy. The working class and elites in Western Europe and South America. Cambridge: Cambridge University Press.

Collier, R., \& Collier, D. (2002). Shaping the political arena. Critical junctures, the labor movement, and regime dynamics in Latin America. Notre Dame, IN: University of Notre Dame Press.

Della Porta, D. (2014). Mobilizing for democracy. Comparing 1989 and 2011. Oxford: Oxford University Press.

Diwan, I., \& Galal, A. (2016). The Middle East economies in times of transition. London: Palgrave Macmillan UK.

Durac, V. (2015). Social movements, protest movements and cross-ideological coalitions: The Arab uprisings re-appraised. Democratization, 22(2), 239-258.

Eckstein, S. (1989). Power and popular protest. Latin American social movements. Berkeley, CA: University of California Press.

Fishman, R. (1990). Rethinking state and regime: Southern Europe's transition to democracy. World Politics, 42(3), 422-440.

Goldfrank, B. (2011). The left and participatory democracy: Brazil, Uruguay, and Venezuela. In S. Levitsky \& K. Roberts (Eds.), The resurgence of the Latin American left (pp. 162-183). Baltimore, MD: The Johns Hopkins University Press.

Goodwin, J. (2001). No other way out. States and revolutionary movements, 1945-1991. Cambridge: Cambridge University Press.

Guazzone, L., \& Pioppi, D. (2012). The Arab state and neoliberal globalization. The restructuring of state power in the Middle East. Reading: Ithaca Press.

Hamzawy, A. (2017). Egypt's resilient and evolving social activism. Washington, DC: Carnegie Endowment for International Peace.

Heydemann, S. (2016). Explaining the Arab uprisings: Transformations in comparative perspective. Mediterranean Politics, 21(1), 192-204. 
Hinnebusch, R. (2015). Globalization, democratization, and the Arab uprising: The international factor in MENA's failed democratization. Democratization, 22(2), 335-357.

Huber, E., \& Stephens, J. (2012). Democracy and the left. social policy and inequality in Latin America. Chicago, IL: The University of Chicago Press.

IMF (International Monetary Fund). (2014). Toward new horizons: Arab economic transformation amid political transitions. Washington, DC.

Karl, T. (1990). Dilemmas of democratization in Latin America. Comparative Politics, 23(1), 1-21.

Kienle, E. (2015). Changed regimes, changed priorities? Economic and social policies after the 2011 elections in Tunisia and Egypt. Economic research forum working paper 928. Retrieved October 25, 2018, from http://erf.org.eg/wp-content/ uploads/2015/12/928.pdf.

Kurtz, M. (2004). The dilemmas of democracy in the open economy. Lessons from Latin America. World Politics, 56(1), 262-302.

Levitsky, S., \& Roberts, K. (2011). The resurgence of the Latin American left. Baltimore, MD: The Johns Hopkins University Press.

Luna, J. P., \& Filgueira, F. (2009). The left turns as multiple paradigmatic crises. Third World Quarterly, 30(2), 371-395.

O'Donnell, G. (1993). On the state, democratization and some conceptual problems: A Latin American view with glances at some postcommunist countries. World Development, 21(8), 1355-1369.

O’Donnell, G., \& Schmitter, P. C. (1986). Transitions from authoritarian rule. Tentative conclusions about uncertain democracies. Baltimore, MD: The Johns Hopkins University Press.

Oxhorn, P. (1998). Is the century of corporatism over? Neoliberalism and the rise of neopluralism. In P. Oxhorn \& G. Ducatenzeiler (Eds.), What kind of democracy? What kind of market? Latin America in the age of neoliberalism (pp. 195-217). University Park, PA: The Pennsylvania State University Press.

Paciello, M. C. (2013). Delivering the revolution? Post-uprising socio-economics in Tunisia and Egypt. The International Spectator, 48(4), 7-29.

Portes, A., \& Hoffman, K. (2003). Latin American class structures: Their composition and change during the neoliberal era. Latin American Research Review, $38(1), 41-82$.

Roberts, K. (2008). The mobilization of opposition to economic liberalization. Annual Review of Political Science, 11, 327-349.

Roll, S. (2016). Managing change: How Egypt's military leadership shaped the transformation. Mediterranean Politics, 21(1), 23-43.

Rossi, F. (2015). The second wave of incorporation in Latin America: A conceptualization of the quest for inclusion applied to Argentina. Latin American Politics and Society, 57(1), 1-28.

Rossi, F. (2017). The poor's struggle for political incorporation. The Piquetero movement in Argentina. Cambridge: Cambridge University Press. 
Rueschemeyer, D., Huber Stephen, E., \& Stephens, J. (1992). Capitalist development and democracy. Cambridge: Polity Press.

Schlumberger, O., \& Matzke, T. (2012). Path toward democracy? The role of economic development. Swiss Political Science Review, 18(1), 105-109.

Silva, E. (2009). Challenging neoliberalism in Latin America. Cambridge: Cambridge University Press.

Silva, E. (2017). Reorganizing popular sector incorporation: Propositions from Bolivia, Ecuador, and Venezuela. Politics \& Society, 45(1), 91-122.

Silva, E., \& Rossi, F. M. (2018). Reshaping the political arena in Latin America: From resisting neoliberalism to the second incorporation. Pittsburgh, PA: University of Pittsburgh Press. forthcoming.

Skocpol, T. (1979). States and social revolutions. A comparative analysis of France, Russia, and China. Cambridge: Cambridge University Press.

Teti, A. (2012). The EU's first response to the 'Arab spring': A critical discourse analysis of the partnership for democracy and shared prosperity. Mediterranean Politics, 17(3), 266-284.

Tilly, C. (1993). European revolutions, 1492-1992. Oxford: Blackwell.

Valbjørn, M. (2012). Upgrading post-democratization studies: Examining a repoliticized Arab world in a transition to somewhere. Middle East Critique, $21(1), 25-35$.

Van Cott, D. L. (2008). Radical democracy in the Andes. Cambridge: Cambridge University Press.

Weipert-Fenner, I. (2015). Making the crisis visible: A reassessment of the parliament in the Mubarak regime. In L. Sadiki (Ed.), Routledge handbook of the Arab spring: Rethinking democratization (pp. 215-226). London: Routledge.

Weipert-Fenner, I., \& Wolff, J. (2015). Socioeconomic contention and postrevolutionary political change in Egypt and Tunisia: A research agenda. PRIF working papers 24. Retrieved October 25, 2018, from http://www.hsfk.de/ fileadmin/HSFK/hsfk_downloads/PRIF_WP_24.pdf.

Wolff, J. (2005). Ambivalent consequences of social exclusion for real-existing democracy in Latin America: The example of the argentine crisis. Journal of International Relations and Development, 8(1), 58-87.

Wolff, J. (2007). (De-)mobilising the marginalised. a comparison of the argentine Piqueteros and Ecuador's indigenous movement. Journal of Latin American Studies, 39(1), 1-29.

Wolff, J. (2018). Political incorporation in measures of democracy: A missing dimension (and the case of Bolivia). Democratization, 25(4), 692-708.

Yashar, D. J. (2005). Contesting citizenship in Latin America. The rise of indigenous movements and the postliberal challenge. Cambridge: Cambridge University Press.

Zorob, A. (2013). Der Zusammenbruch des autoritären Gesellschaftsvertrags. Sozio-ökonomische Hintergründe der arabischen Proteste. In A. Jünemann \& A. Zorob (Eds.), Arabellions. Zur Vielfalt von protest und Revolte im Nahen Osten und Nordafrika (pp. 229-256). Wiesbaden: Springer. 
Open Access This chapter is distributed under the terms of the Creative Commons Attribution 4.0 International License (http://creativecommons.org/ licenses/by/4.0/), which permits use, duplication, adaptation, distribution and reproduction in any medium or format, as long as you give appropriate credit to the original author(s) and the source, a link is provided to the Creative Commons license and any changes made are indicated.

The images or other third party material in this chapter are included in the work's Creative Commons license, unless indicated otherwise in the credit line; if such material is not included in the work's Creative Commons license and the respective action is not permitted by statutory regulation, users will need to obtain permission from the license holder to duplicate, adapt or reproduce the material. 